\title{
Past, Present and Future of Urban Agriculture in Cameroon: Major Contemporary Challenges (1993-2017)
}

\author{
Theodore Ngoufo Sogang, Youssouf Monkouop* \\ University of Dschang, Dschang, Cameroon \\ Email: ngoufotheodore@yahoo.fr, ^njimonkouop.youssef@yahoo.fr
}

How to cite this paper: Ngoufo Sogang, T. and Monkouop, Y. (2022) Past, Present and Future of Urban Agriculture in Cameroon: Major Contemporary Challenges (19932017). Journal of Agricultural Chemistry and Environment, 11, 1-14.

https://doi.org/10.4236/jacen.2022.111001

Received: October 8, 2021

Accepted: January 17, 2022

Published: January 20, 2022

Copyright $\odot 2022$ by author(s) and Scientific Research Publishing Inc. This work is licensed under the Creative Commons Attribution International License (CC BY 4.0).

http://creativecommons.org/licenses/by/4.0/

\begin{abstract}
In the $21^{\text {st }}$ Century, Food and Agricultural stakes are sinuously rushing in a difficult legible heading. Crossing a transitory phase period between Agriculture, Traditional, Urban and Modern, the affirmation of a conquering alimentary identity and Nationalist openings is confuse with an Extraordinary Demographic Period of human scale history. Millions of people are worried about the innovation of urban agriculture for food and health security. Food education at the confines of the world's greatest stakes proves necessary, since the order oneself retreat combines with the passion of solidarity and social progress, advance in technology, facilitating our life at same time generating new threats for citizenship. In this Article, we propose another way of reading the heterogeneous world of yesterday, today and tomorrow. Not only for Historians but also by associating Scientific Relations of Social and Human Researchers. Such a step is necessary to endorse the word of reading, for comparism and review of an agriculture in full mutation. It also instigates by referring to History, Social force, Economic stakes and Diplomatic globalization food teste, intention and invention, which change with the everyday society. You will find out that analysis done in this article are sometime completely done events through original texts, assembled around the five fundamental notions: International Relations and Geopolitical Agriculture of yesterday; Yesterday Urban Economic Agriculture; Environmental and Food Climate Stakes, Science and Culture adapted to agriculture and food mutations.
\end{abstract}

\section{Keywords}

Yesterday Urban Agriculture, Food Stakes, Geopolitics of Agriculture, Contemporary World 


\section{Introduction}

Urban agriculture is a prominent feature of the urban landscape in Cameroon today. It consists of moving the agricultural production system from the rural world to urban centres but modernising it. At a time when urbanisation rates are approaching 50\% everywhere, urban agriculture has paradoxically intensified, bringing in various challenges. At first, it was practiced only during a crisis period, but gradually it became a permanent activity In December 2008, in a research paper on the environmental impact of urban agriculture in Yaoundé, Prosper Asaa Nguegang [1] pointed out that, in the lowlands of Cameroon's capital city, watercourses are often used for watering and maintaining plants that are directly consumed by the population. This is not good for the economy and constitutes a danger to the health of the urban population. Cameroon, so far considered as the granary of Central Africa and counted among the great agroecological zones of the world, is faced with the challenges of urban agriculture today and tomorrow, given the development of this sector of activity in the urban cities of Cameroon, especially in the largest agglomerations of Yaoundé and Douala. The country is on the borderline of issues that are difficult to understand because of the harmful effects that this activity generates. So, what are the issues and challenges of urban agriculture, knowing that we are moving from traditional agriculture to modernization and the growing need for food in urban cities in Cameroon? Our approach is to present the practice of urban agriculture in Cameroon between the traditional activity of yesterday, and the factors of crystallization of this activity today, in the face of the challenges and issues of the contemporary world.

\section{Urban Agriculture in Cameroon between Traditional Activity of Yesterday and Factors of Crystallisation}

Considered as the base of developments, agriculture has crystallised the ambitions of Man since His appearance in the natural and vital environment. Urban agriculture started in Cameroon from the currency devaluation crisis of 1993 and has become more and more pronounced in 2008, the year of the crisis rightly or wrongly called the "2008 Hunger Riots". Thus, urban and peri-urban agriculture increased in Cameroon, particularly in the agglomerations of Douala and Yaoundé, the country's economic and political capital respectively. Practical cases in the city of Yaoundé will be analyzed.

\subsection{Urban and Peri-Urban Agriculture in Yaounde: A Historical Analysis}

Urban and peri-urban agriculture in Yaounde is a growing activity in the survival economy and contributes to the supply of seasonal fruits and vegetables to the population. Market gardening and food crops were introduced gradually in the two main cities of Cameroon. However, this activity only gained momentum from 1980 onwards [2]. In Yaoundé, peri-urban agriculture dates from the 1980s 
according to Moustier [3]. Hernandez, on the other hand, shows that market gardening in the peri-urban area of Yaoundé is ancient and dates back to before independence in the Nkolbikok, Okolo and Nkolondom districts. From these two authors, we note that indigenous peoples and expatriate settlers inhabited Yaoundé, long before Cameroon's independence. Urban agriculture was therefore practiced in Yaoundé before Cameroon's independence, as each people moved with its own cultures and some of its food habits.

To this end, the diagnosis of inflation in the price of market garden products and the urgent need for the colonists to acclimatize to the indigenous way of life and taste for food quickly pushed the residents of the localities to come and settle there. This equally pushed the populations of the rural areas to develop the activity, which was considered to be remunerative in the short term, allowing them to support their families. This urban agriculture, which has disregarded cultivation methods and hygiene rules over the years, poses a health issue as well as a problem for the modernisation of urban centres, which the public authorities and the populations themselves are now facing. This practice encourages urban disorder, the promiscuity of unregulated markets, and the insecurity of consumers of these foods due to the non-respect of production rules.

Urban and peri-urban agricultural activity is therefore part of a historical process and includes, among other things, market gardening, food production and small-scale livestock farming. Several reasons or motives militate in favour of this activity. Despite the land and environmental constraints, the socio-economic impact at the family and macroeconomic levels is known. It should be noted that the deterioration of the economic situation and a significant demographic growth that were observed after the County's Independence contributed to the downfall of urban tissues and the emergence of precarious quarters in the urban zones of Yaoundé and Douala, with an annual urban growth $>5 \%$. According to the UNO Population, about $60 \%$ of the population plays a multifunctional role, which leads to poorly controlled marketing system.

The products of these agricultural activities are then used for the consumption for the farmers, and are equally commercialized in different markets of the city of Seven Hill. The sale of fresh vegetables has become commonplace in various intersections of the city of Yaoundé, thus making it easy for households to have fresh vegetable In the Zibi, Nkomkana, Melen and Bankolo neighbourhoods, young people often take advantage of school holidays and are at the forefront of the maket. They offer 'folong', the large nightshade in bowls or in a wheelbarrow for 100 FCFA to the inhabitants of this area, which winds around Camp Sic Mendong, in the the Yaoundé 6 subdivision. Some even boast, "Our vegetables are fresh, really fresh," "Our vegetables are cut here in Yaoundé," say the young girls haggling with the local housewives. "My mother has a garden," says one of the saleswomen casually. On this hilly road of the locality of Zibi located behind the Camp SIC Mendong in the Yaoundé 6 subdivision, one can see fields on the sides of the hills. In this rapidly growing town, small farms are also flourishing around the houses. Furrows and ridges are used to grow corn in all seasons. 
Further away, and close to the houses, women and young boys are busy working on well-defined plots. "It's like this with the return of the rains. Everyone wants to have their own little maize and bean field," explains Martine, a housewife. In addition "after the maize, we'll make a vegetable garden that we'll sell at the Mendong market", adds another woman with a hoe in the hand. It is easy to understand that this farming activity in the urban areas also serves as a source of income for these housewives. Given the need and the path that agriculture is taking in urban cities, especially in Yaoundé, the political capital of Cameroon, it is more than urgent that urban policies and public authorities look into this matter in order to foresee the medium and long-term difficulties that they will be forced to solve.

\subsection{Factors of Urban Agriculture Development in Cameroon}

In Yaoundé, the deterioration of the economic situation, combined with strong demographic pressure, has contributed to the decay of the urban tissue and the emergence of precarious areas. This situation poses the challenge of feeding all this population, while ensuring the state of their health. With an annual urban growth rate of over $5 \%$, according to UN-Population, approximately $60 \%$ of the Cameroonian population will be living in an urban context by 2020. Thanks to the support of Québec Sans Frontière and the Louise Grenier Foundation, Alternatives et PROTEGE QV supported the development of an urban agriculture programme in the Biyem-Assi district, a populated areas in Yaoundé, in order to reduce poverty and food insecurity among the inhabitants. Based on a non-soil farming technique developed by Alternatives as part of the rooftop garden project in urban centres, the NGO's initiative made it possible to produce fresh vegetables in an urban area that is increasingly covered in concrete, where arable land is scarce and often contaminated. The initiative included the development of vegetable gardens and a school garden, the creation of income-generating activities, the design of a training programme in urban agriculture, educational activities (writing of a pedagogical guide, radio programme, kiosk), the environment and the importance of a balanced diet.

\subsubsection{Actors of Urban Agriculture in Cameroon}

In Yaoundé, the majority of market gardeners are people who previously carried out another activity. They were forced to abandon the first activity due to lack of profitability (Hernandez, 1999). In 1996, 35\% of city dwellers in Cameroon were involved in urban agriculture (Smith, 2002). It is important to note the great diversity of actors encountered in urban and peri-urban areas. The categories of actors can be cited as follows:

Producers (professional farmers): Agriculture is the only, if not the main source of income in urban and peri-urban areas for these people. Surveys carried out by CIPRE in 2002 [4] in Yaoundé show that producers include housewives, people who have been made redundant from private and public enterprises, pensioners, the unemployed, etc. 
Agricultural Workers: These are often people who make their labour force available to farmers. They are students, pupils, apprentices as well as women who may be placed as labourers or temporary workers [2].

Occational Agricultuist: These are men and women for whom urban agriculture is a second activity. These actors are found among the resourceful in the informal sectors, small-scale artisans, low-income civil servants, and even smallscale domestic farmers. In general, their work is carried out at weekends, on public holidays and often in the evening [4].

Horticulturists: Generally, these men produce and sell flowers, ornamental plants and fruit trees. They sometimes play the role of naturopath for some of their clients, and are generally installed on a regular basis around the major intersections of the urban centre. They can be found in Yaoundé in the Ekozoa valley and at many crossroads in the city.

Producers of Vegetal Materials: These are mainly men who have made planting material or seed production their profession. They are mainly agricultural technicians who produce and sell grafted seedlings, oil plants, and seeds (maize, beans) for resale to urban and peri-urban farmers.

Agricultural Input Suppliers: These include large firms producing and marketing plant protection products, wholesalers specialising in the sale of inputs, semi-wholesalers and even retailers. Chemical fertilisers, pesticides, seeds and small agricultural equipment constitute the bulk of their goods.

Consumers: Urban consumers for whom finished or semi-finished products are intended only react individually in their overall appreciation of the products. Through the analysis of Food Supply and Distribution Systems (FSDS) among the wealthy, middle class and poor in a city, the importance of the performance of the different stakeholders can be understood..

Students: This is a category of farmers who only appear during the major school holidays (June-September). Pupils and students, especially those from localities where farming is traditional, work to prepare the back to school (purchase of school items, payment of school fees).

A study conducted by Nguegang in 2002 within the framework of PADIAUP among 38 associations, ICGs and urban and peri-urban farmers groups in the city of Yaoundé shows that these actors make a real contribution to food supply through the diversity and quantity of their production. Urban and peri-urban agriculture also serves as a "shock absorber" for the less poor during periods of crisis to maintain certain levels of food security. The many urban female farmers are most likely to use income from agriculture to feed their families.

\subsubsection{Urban and Peri-Urban Agriculture: A Rising and Controversial Activity}

Urban and peri-urban agricultural activity is part of a historical context and includes, among other things, market gardening, food production and small-scale livestock farming. Several reasons or motives militate in favour of this activity in Cameroon. Despite the land and environmental constraints, the socio-economic 
impact at the family and macroeconomic levels is known. Urban agriculture is defined as the cultivation of plants and the raising of animals in urban areas for food consumption and other purposes. Production includes tubers, vegetables, aromatic and medicinal herbs, fruits and animal husbandry, especially poultry. The most represented food crops are vegetables and the most perishable and high value-added livestock products and by-products.

According to Temple (2002) [5], in Yaoundé there are food crops (cassava, groundnuts, maize, and potatoes), market garden crops (leafy vegetables and fruits), floral and ornamental crops and fruit crops (papaya, mango, etc.). The main animal productions in Yaoundé are broiler chickens, pigs, goats and sheep, ducks and pigeons.

Indeed, the large Cameroonian metropolises are experiencing significant spatial growth, one of the major constraints of which is the land issue, with the corollary of competition over land use between agricultural and non-agricultural activities. This form of agriculture plays a daily role in feeding the city, particularly with fresh products, which is confronted with various difficulties, including access to land, which threatens its sustainability and makes this activity precarious.

Urban and peri-urban agriculture is an activity that is almost unique to lowland swamps. These lowland swamps are in the public domain and are therefore likely to be owned by the state (despite the fact that without a land title even the state cannot appropriate this land). This means that from time to time urban farmers are threatened with eviction.

With regard to the areas of land that are exploited, we learn that they are of several kinds. Firstly, the owners who have not yet started their construction make them available to farmers. This is a way of securing one's plot of land. In other cases, the land is rented from private individuals, usually local people. For this last option, the amounts depend on the surface area. For one hectare, for example, it is possible that the rent reaches 100,000 FCFA during the agricultural season. Besides, the localities of Etoug-Ebé and Nkolbisson are traditional agricultural zones in Yaoundé. The population has taken other localities in charge. There is a strong pressure dominating new periphery quarters like Soa, Nkolondum, Eloumden etc. Market gardening occupied an important place. Beside tomatoes, vegetable and pepper, we have species in all its forms for market provision in Yaoundé.

\section{The Stakes and Challenges of Urban Agriculture and the World Challenges}

The challenging issue to be solve by public authorities is to feed a growing population by favoring the development of towns and by assuring the good health of foods and consumers. However, How to feed a population and at the same time develop urban center without compromising the future of the coming generation? Given that the world of today is facing great threats such as climate change, demographic explosion, exhaustion of fossil energy, the health of foods and people 
in the urban area, it becomes important to question the stakes of an urban agriculture and the challenges facing Africans in general and Cameroonians in particular in the urbanization process.

\subsection{The Stakes of Urban Agriculture in the Urbanization Process of Towns in Cameroon}

The main agricultural stakes of the contemporary world require that a serious country should introduce in school programmes the study of the geopolitical food system its urban agricultural territory. This could help solving problems such as:

- Nutritional help and massive import of foodstuff. Nutritional help brought in countries in situation of food insecurity to desperate persons are also an indicator of underdevelopment and is generally a sign economic dependence. It undermines the spirit of entrepreneurship in these countries.

- Hunger: This is a situation of food crisis, during which the population only have a very small quantity of daily food, which can lead death.

- Food insecurity, which is the fact of feeding the population with insufficient quality and quantity of food.

\subsubsection{The Advantages of Urban and Peri-Urban Agriculture}

Today, urban agriculture is booming because of accelerated urban growth, which is often motivated by the search of food security and the improvement of citizens' wellbeing. It contributes significantly to feeding the various households of different population groups in cities in developing countries. It equally help the citizens (producers, transporters, sellers and consumers) to gain their life.

Contribution to Food Supply: A study carried out by Ngougang (2002) within the PADIAUP framework of 38 Associations, ICG, and Farming, urban and peri-urban groups in Yaoundé city, shows that those actors really contribute to supply the diversities and quantity of their production. Urban and peri-urban zones serves as an absorber for the less poor in times of crisis in order to maintain a certain level of food security. Most female farmers are likely to use their agricultural revenue to feed their family.

Gockowski and $\mathrm{Al}$ [6] (2003) reveal that in the Yaoundé, 41\% of the poorest urban households consume vegetables produced in their garden. The same study shows that household production in urban areas represent $10 \%$ of the total household consumption. According to Saua and $\mathrm{Al}, 64 \%$ of households exploit the lowland of Yaoundé of Yaoundé for consumption.

Contribution the Reduction of Unemployment Rate: In the city of Yaoundé, as in all African cities, many city dwellers develop small-scale livestock (pigs and rabbits), poultry (fowls and ducks), produce vegetables, species, fruits and flowers [4], and this contribute to significantly reduce the unemployment rate. The interest in this activity is due not only to cultural habits, but also to unemployment and poverty affecting young people, who consider the activity as a refuge. Faced with this situation, agriculture appears to be a new employment potential 
to others; women and young people are now the main actors in this field of activity, which has become important over time. It is important to note that in the city of Yaoundé, urban and peri-urban agriculture is developing much more in the swampy lowlands as mentioned above. The marketing products and their processing in street food restaurant equally employ more women and young people who see it as an important source of income. Despite their importance, all these indirect jobs are difficult to number.

With lucrative activities of formal and informal sectors more or less saturated, poverty has reached worrying rates, putting $30 \%$ of the population of the Yaoundé city at risk and food insecurity affecting $28 \%$ of this population. Thus, in order to survive or improve their income, unemployed youths are forced to engage in agricultural activities in swampy lowlands or in any available public space in the urban perimeter. Table 1 shows the urban poverty index in Cameroon, published in 1999 by the PNUD. Unfortunately, this index is still relevant today.

This table, published by the Assistant programme to the Integrated Urban and Periurban Agricultural Development of CIPRE in 2002 [4], shows the constancy of the precariousness index, which pushes many young people in peri-urban areas to engage in urban farming by devoting their labour power to it in order to survive.

Contribution to Urban and Peri-Urban Planning: Urban Horticulture (market gardening and floriculture) help to conserve green spaces within the built-up area; has a real ecological value and contributes to urban and peri-urban development. It conceals It equally contains a wealth of plant and animal life that is important for maintaining biodiversity. The different facets of its environmental functions shows that its use for farming agricultural purpose and its protection can contribute in maintaining the ecological balance of the region as a whole. According to CIPRE (2002) [4], the full expansion of Horticulture in the city of Yaoundé, as well as forestry in the flooded lowlands, also contribute to the improvement of urban architecture. It's because of the role it plays in urban development that the World Environment Day was celebrated on 5 June 2005 under the theme "Green Cities, a Plan for the Planet...", and that of 5 June 2017 "Bringing People Closer to Nature".

\subsubsection{Environmental Challenges of Urban Agriculture for the World}

The Environmental stakes linked to urban agriculture are increasingly well

Table 1. Urban poverty index.

\begin{tabular}{cccc}
\hline \multicolumn{2}{c}{ Urban Areas } & \multicolumn{2}{c}{ Rural Areas } \\
\hline Percentage & Distribution & Percentage & Distribution \\
\hline 21.4 & Savannas & 56.7 & Yaoundé \\
19.7 & Forests & 63.8 & Douala \\
29.6 & High lands & 66.0 & Other urban zones \\
\hline
\end{tabular}

Source: Pnud-Yaoundé, 1999. 
targeted and apprehended by most developed countries. This particularly concerns the protection of resources and environments (quantitative and qualitative water management, protection of agricultural soils and the health of the population.) It is in this perspective that the Horizon 2020 Programme aims at improving the productivity and sustainability of agriculture and forestry while strengthening food and non-food sectors. It equally intends to provide the rural population with means to stimulate economic diversification and the supply of food with proteins. In the coming years, the global food and agriculture system will have to meet the needs of billions additional people and the situation of agricultural markets. A better stability of must be found between national priorities and the common good of humanity. Africa and Cameroon in particular, which will not be left out, therefore share the potential to create a food market of 1000 billion dollars. To this end, farmers need to be helped to improve their crops and better market their products. The economic, financial and food crises that hit the world in 2007 and 2008, and whose shockwaves are still spreading, have left their mark in West Africa and mostly the in the Central African countries. Although many authors have examined the manifestations and consequences of these crises, very few have been understood. This made it necessary to write this paper on the Mutation of Rural World in Cameroon transformed into city.

\subsection{The Challenges of Urban Agriculture Face to Global Issues}

The issues and challenges of urban agriculture are the preservation of the ecology, the control of demography by adapting production to the growth and by solving the problems related to agricultural land in urban centres. We also have the issue of agro-fuel which will facilitate mobility in urban centres and which is an integral part of the major challenges of the contemporary world and of $\mathrm{Ca}$ meroon in Particular.

\subsubsection{The Challenges and Disadvantages of Urban Agriculture in Cameroon}

The negative effects of urban and peri-urban agriculture are numerous. The most visible ones, which most often lead to the unfavourable perception of urban agriculture by city administrators, are the use of waste (especially wastewaters) and pesticides, animal droppings, and the roaming of animals. All these are the sources of problems faced by the population and the urban environment.

Impact on Human Health: The utilization of solid and liquid waste in urban agriculture carries important risks for human health. One should be very careful when using waste on vegetable crops whose leaves are directly consumable, as some metals, such as cadmium, accumulate preferentially in leaf parts. As a result, pathogenic viruses, bacteria, protozoa and helminths are passed in the excrement of infected persons and end up in the wastewater that is sometimes used for agricultural services in urban centres.

The transportation of products is one of the important aspects. This is done 
using public transport means that are not specially designed for this purpose. In the markets, market gardeners who do not have specific locations sometimes occupy the roadsides. At the individual, the majority of farmers complain about the lack of means; this problem, although real, is most often the result of their poor management of resources. Another problem is that of input supply. Farmers generally buy their inputs from pesticide dealers, as these dealers are often of dubious competence and morality. So it will be less risky to buy from reliable firms. Diseases can be transmitted orally (by eating contaminated vegetables) or through the skin (in the case of hookworms and schistosomiasis). Farmers, as well as consumers are at risk of food poisoning from the misuse of pesticides or the use of outdated ones. Similarly, the constant handling of pesticides exposes producers to various health risks (skin and eye irritation, alteration of the reproductive or nervous system, etc.).

The risk of water-borne diseases should also be noted: typhoid, amoebic dysentery, and bilharzia. A study carried out by Kamgnia in 2004 on the Analysis of the Impacts of the distribution on Public Health expenditures in the incidence of patients' recourse to Public Health Structures in Cameroon, shows that to fight against poverty, Cameroon's Government increased it health expenditures since 1990s.

Impact on the Environment: the environmental impact of urban agriculture favours the pollution of soils and groundwater by pesticides during phytosanitary treatments or chemical fertilisers during soil fertilization. It facilitates the proliferation of mosquitoes, vectors of malaria in poorly maintained irrigation basins. According to a recent warning from the FAO and WHO, about $30 \%$ of commercialized pesticides in developing countries do not comply with International Quality Standard and represent a danger to health and the environmental. Chemical products containing dangerous substances and impurities that are banned or strictly limited are used in farming in Yaoundé and Douala. The following risks are noted in this respect: the destruction of useful fauna and flora (birds, fish, bees, etc.), the pollution of the urban atmosphere and ecosystem imbalance.

However, beyond these multiple nuisances, urban farmers themselves generally face problems such as lack of land, high cost of inputs, lack of training and information on the opportunities of agriculture, diseases, harassment by municipal agents and landowners, etc. It is due to the conflicts between urban farmers and municipal authorities, who are all farmers (given that the City Council of Yaoundé or the council want to evict them to plant eucalyptus on their plots) that a workshop on the development of urban and peri-urban agriculture in West and Central Africa was held in Yaoundé. For several days (from the $30^{\text {th }}$ October and $4^{\text {th }}$ November 2005), more than 200 specialists on environmental, demographic, urban and economic issues met with decision-makers and farmers in order to enlighten each of the parties (State and urban farmers) concerning the role they should play for African cities to be beautiful and less polluted.

Sanitary Risks: the scarcity of the farmable land brings several health risks, 
for studies on the use of fertilizers to improve yield were carried out. In December 2008, Asaa, Nguegang, in a highly refined research paper on the environmental impact of urban agriculture in Yaoundé, pointed out, for example, that in the lowland areas of the city, streams are often used for watering. This is not without risk for producers and consumers. According to biochemists from the University of Yaoundé I, these streams contains high organic elements. The studies, for example, indicated that in the Nkolbisson valley, values of biochemical oxygen demand $(>116 \mathrm{mg} / \mathrm{L})$ were identified, thus testifying to an environment of high organic pollution. According to the hypothesis of these biochemists, five diseases have been reported among the market gardeners. These were malaria, typhoid, fever, diarrhea, Bilharzia and Amoebiasis. It was concluded that the prevalence of typhoid, fever, diarrhea and amebiasis might be due to the consumption of plants and raw vegetables soiled during the watering and packaging of certain foods. The risk would be high if the Ministry of Agriculture and Rural Development did not take a closer look at urban agriculture. Since few controls are carried out on the use of fertilizers, vegetables can be found in Yaoundé at any time.

\subsubsection{Urban Discharges and Urban Wastewater Treatment Mechanisms and Strategies for Agriculture}

The issue of household waste management is unfortunately of little concern to our society, whereas a pragmatic, although partial, approach to this problem consist in encouraging the recycling of part of the urban waste in agriculture according to the acceptable methods and standards. Moreover, a programme led by World Engineering, the World Bank, actors of the private sector and NGOs has made this its main objective. In the first report of this programme, the basic concepts of agricultural recycling was described. On the one hand, cities produce large quantity of waste, rich in water, organic and mineral materials, which are either discharged directly into nature, watercourses, or disposed of by landfilling, incineration or treatment in sewage plants. On the other hand, urban agriculture is forced to intensify, consuming large quantities of fertilisers (most often imported) and water drawn from drinking water resources. A new strategy could, on the contrary,aim at creating links between urban waste management and agriculture, without jeorpardising the industrial and economic development of cities. This strategy is based on waste treatment techniques that should result in co-products to be easily used by the farmer, without any health hazards and with minimal risk to the natural environment.

New urban agricultural inputs, cultivation techniques and food maintainance and conservation methods in Cameroon's urban areas such as Yaoundé and Douala, appear to be very dangerous to the health of city dwellers. This is because they are new in terms of technology or use, or sometimes based millennium principles in order to facilitate the consumption of fruit or raw vegetables. Farmers in these areas resort to unorthodox methods of cultivation and use of dangerous elements that threaten the health of the population in most part. Per- 
haps a simple return to the basics of agronomy in the production basins and rural areas can remedy the problem and facilitate the new green revolution, which would be a simple return to the roots where real technological innovation must take the lead to supply urban areas by ensuring their health, which remains a major challenge for the public authorities. Some name it sustainable or integrated conservative agriculture. Others call it ecologically intensive or high environmental value agriculture. As a matter of priority, a consensus for an Agriculture that reconciles food and agro fuel must be found in order to serve a rapidly growing population with a limited agricultural area. Ecology, pesticide residues, water pollution, biodiversity and landscape improvement are the challenges of the day that must be urgently addressed to avoid disastrous consequences in the future. This is why PROTEGE QV, with the help of Loouise Grenier Foundation and Alternatives, a Canadian NGO and APC member, has been carrying out a project to promote urban agriculture in Biyem-Assi, a working class neighborhood in Yaoundé-Cameroon. The project aimed at building the capacity of at least small-scale farmers in large urban areas to produce sustainable food in order to protect the environment and preserve their lives (Figure $1 \&$ Figure 2).
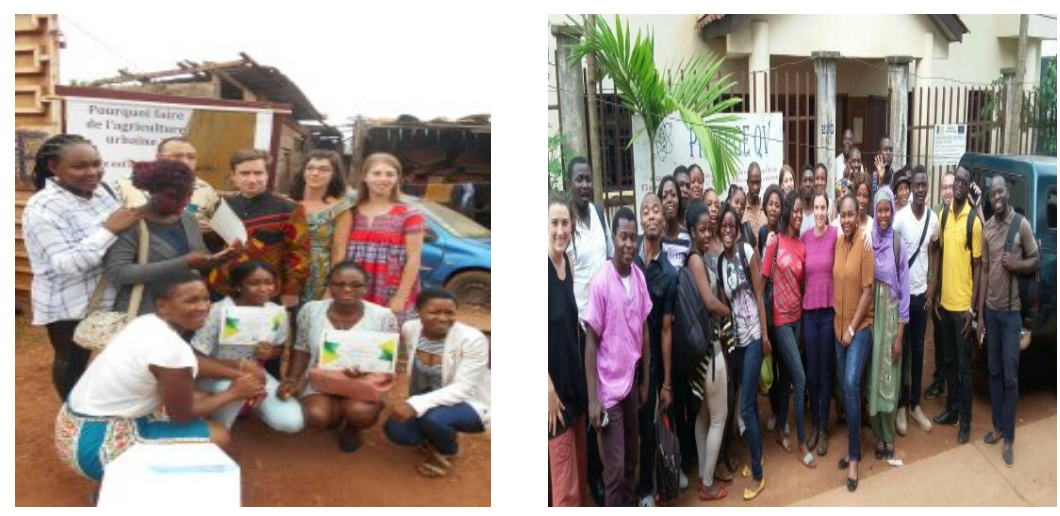

Figure 1. PROTEGE QV" with the support of the Louise Grenier Foundation and Alternatives, a Canadian NGO also a member of APC, PROTEGE QV carried out a project to promote urban agriculture in Biyem-Assi, a working-class district of Yaoundé, Cameroon. Cliché Youssouf M.: the graduation ceremony of the participants following the training organized on 21 April-19 June 2017.

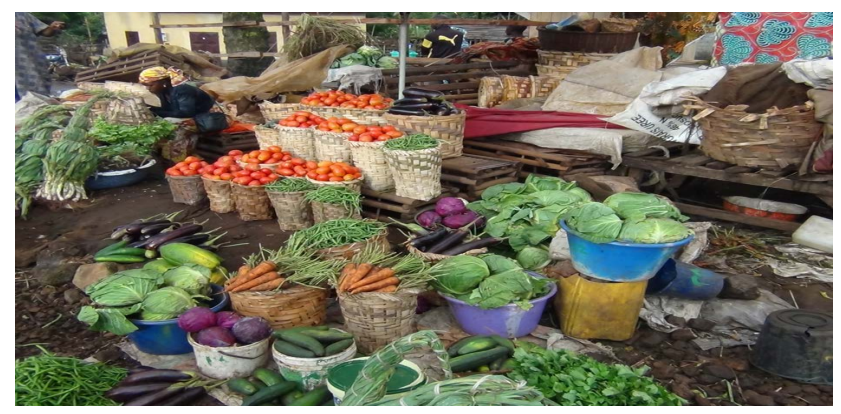

Figure 2. Illustration of some fresh food grown and marketed in the city of Yaoundé: $8^{\text {th }}$ market in NKomkana. Cliché youssouf M. (2017). 


\section{Conclusion}

Agriculture in its large meaning is the practice of growing crops or raising animals useful to man. Besides the cultivation of vegetables, we have rearing, fishing and hunting activities. This research consisted in assessing the stakes and challenges of an urban agriculture in Cameroon. Findings show that agricultural inputs such as fertilizers, pesticides and other chemical constituents are used to produce more foods, but these foods are directly consumed by the population without undergoing any consumption standard. Even though, as Tchakonte et al. [7] in their study demonstrate, agriculture, unlike urbanization, pollutes less the environment, the question is, if the rural agriculture at certain point is no more able to consumption needs, there will be the need to turn to the urban and peri-urban agriculture to fill the gap. By so doing, the usage of chemical elements will increase and the pollution level as well, given that agriculture, rearing and fishing occupies an essential place in Cameroon's economy. So far, the solution has usually consisted in importing large quantity of products, which could be produced locally. President Paul Biya's policy of "Great Achievements" is then put in place to encourage and develop Cameroon Agriculture in order to make a significant increase of the country's growth. This policy consists in accelerating the modernization of agriculture, and creating special incitement adapted to modern agriculture and investment code. Other measures concern the creation of an assistant bank to the agricultural sector. We can equally list the restructure of chemical industry in favor of Agro-industries and the new generation of agricultural studies adapted to Cameroonian realities to encourage the development of the agricultural sector in the country. Paul Biya's objective is thus to assure the auto sufficiency of Cameroon's food and avoid Rural Exodus.

\section{Conflicts of Interest}

The authors declare no conflicts of interest regarding the publication of this paper.

\section{References}

[1] Nguegang, A.P. (2003) Situation et Perspectives sur l'Agriculture et périurbaine à Yaoundé. Memoire DES, Belgique, 1-74.

[2] Schilter, C. (1991) Urban Agriculture: An Activity That Creates Jobsin a Survival Economy; the Case of Lomé. Cahiers des Sciences Humaines, 27, 159-168.

[3] Moustier, P. and Pages, J. (1997) Peri-Urban Areas in Africa: Agriculture on te Fringes? Economie Rurale, 241, 48-55. https://doi.org/10.3406/ecoru.1997.4888

[4] CIPRE (2002) L'agriculture urbaine et périurbaine à Yaoundé: Situation d'une activité montante et controversée. Document de Projet, 1-56.

[5] Temple, L., Ganry, J. and Chataigner, J. (1993) Plantain Production System and Prospects for Intensification in the South West of Cameroon. Fruits, 42, 119-123.

[6] Gockowski, J. (1998) Intensification of Horticultural Production in the Urban Periphery of Yaoundé. Agriculture Urbaine en Afrique Subsaharienne, 63-79. 
[7] Onana, F.M., et al. (2021) Effect of Industrial Agriculture and Urbanisation on Structure and Functional Organisation of Microinvertebrate of Coastal Streams in Cameroon. Journal of Water Resource and Protection, 13, 154-171.

https://doi.org/10.4236/jwarp.2021.132009 